\title{
The Formation of Oxygen-Containing Heterocycles via Intramolecular Cyclizations of Halo-substituted Acylsilanes and Unsaturated Acylsilanes
}

\author{
Yeun-Min Tsai,* Chaur-Donp Cherng, Hong-Chang Nieh, and Jiuen-Ahn Sieh \\ Department of Chemistry, National Taiwan University, Taipei, Taiwan 106, Republic of China
}

Received 25 August 1999; accepted 18 October 1999

\begin{abstract}
Halo-substituted acylsilanes undergo cyclizations casily when heated in a polar solvent such as NMP to afford 2-silyldihydrofurans and 2-silyldihydropyrans. Unsaturated acylsilanes undergo cyclizations through reactions with iodine, phenylselenenyl bromide, or chloride. Further reactions of the cyclized products with pyridinium perbromide, phenylselenenyl bromide, or chloride give highly functionalized dihydrofurans and dihydropyrans. $\odot 1999$ Elsevier Science Ltd. All rights reserved.
\end{abstract}

Keywords: Cyclization; Furans; Pyrans; Silicon and compounds.

Acylsilanes exhibit interesting physical and chemical properties, ${ }^{1}$ sparking continued interest in the synthesis and synthetic application of this class of compounds. Synthetically there are two highly distinct features of acylsilanes. The first one is the high electrophilic nature of the carbonyl carbon of acylsilanes, in which the large silyl group is often used as a handle for stereoselective transformations. 1,2 The second one is the existence of several rearrangement possibilities, either directly by photolysis or heating, ${ }^{1,3}$ or through nucleophilic attacks. ${ }^{1,4}$ Recently, acylsilanes have been found to be excellent radical acceptors. ${ }^{5}$

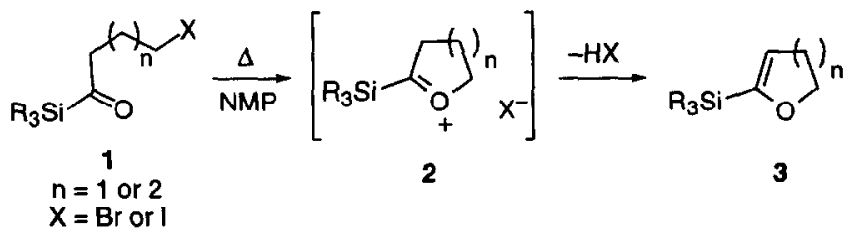

Several years ago we reported the ionic cyclization of halogen substituted acylsilanes give dihydrofurans or dihydropyrans.6,7 As shown in eq 1, this process presumably involves a nucleophilic attack of the carbonyl oxygen at the halogen substituted carbon. ${ }^{8}$ In contrast, aldehydes and ketones do not undergo this similar type of reaction easily, and basic conditions are often used. ${ }^{9}$ This difference may be attributed to the higher basicity

${ }^{*}$ E-mail: ymtsai@mail.ch.ntu.edu.tw 
of the carbonyl oxygen in acylsilanes. 10 Recently, Molander and Siedem reported the cyclization of acylsilane aldehydes generates furans. ${ }^{11}$ The cyclizations of bisacylsilanes under acidic conditions were studied by Saleur, Bouillon, and Portella. ${ }^{12}$ Herein we wish to report the full account of our study on the ionic cyclizations of acylsilanes to produce oxygen-containing heterocycles.

\section{RESULTS AND DISCUSSION}

For the purpose of the study of radical cyclizations of acylsilanes, ${ }^{5}$ we needed to prepare a bromide from $\gamma$-chloroacylsilane 4 (eq 2) via the method developed by Lukevics and coworkers. ${ }^{13}$ Surprisingly, heating chloride $4^{5 a}$ with sodium bromide in $N$-methylpyrrolidone (NMP) at $60^{\circ} \mathrm{C}(12 \mathrm{~h}$ ) in the presence of excess ethyl bromide afforded dihydrofuran 5 in $49 \%$ yield. We found that this type of cyclization is quite general for the bromine substituted acylsilanes. As shown in Table 1 (entry 1), heating bromoacylsilane 6a5a in NMP at $100^{\circ} \mathrm{C}$ for $13 \mathrm{~h}$ gives dihydropyran $7 \mathbf{a}$ in $91 \%$ yield. In contrast, bromide $6 \mathbf{a}$ is stable in refluxing THF or benzene overnight (entries 7,8). Therefore, the use of a polar solvent such as NMP is crucial for the success of the cyclization. The cyclization reaction can also be carried out in DMF (entry 3). Although the reaction proceeds in acetonitrile (entry 5), the rate is too slow to be useful. Because the cyclization reaction also produces one equivalent of hydrogen bromide, we can use one equivalent of triethylamine as an acid sponge (entries 2, 4,6). It is noteworthy that 2-silyldihydropyran is quite stable in the presence of hydrogen bromide as in the case of entry 1 (Table 1 ).

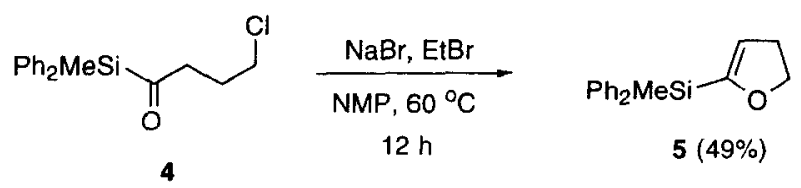

Table 1. The effect of solvent and triethylamine on the cyclization of bromoacylsilane $6 \mathbf{a}$.

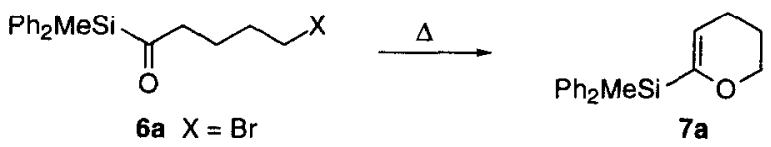

\begin{tabular}{cccccc}
\hline entry & solvent & $\mathrm{Et}_{3} \mathrm{~N}$ (equiv) & temp $\left({ }^{\circ} \mathrm{C}\right)$ & time $(\mathrm{h})$ & yield $(\%)$ \\
\hline 1 & NMP & 0 & 100 & 13 & 91 \\
2 & NMP & 1 & 100 & 6 & 79 \\
3 & $\mathrm{DMF}$ & 0 & 100 & 9 & 79 \\
4 & $\mathrm{DMF}$ & 1 & 100 & 5 & 75 \\
5 & $\mathrm{CH}_{3} \mathrm{CN}$ & 0 & 81 & 23 & $42^{\mathrm{a}}$ \\
6 & $\mathrm{CH}_{3} \mathrm{CN}$ & 1 & 81 & 48 & $55^{\mathrm{b}}$ \\
7 & $\mathrm{THF}$ & 0 & 65 & 7 & c $^{\mathrm{c}}$ \\
8 & Benzene & 0 & 80 & 8 & c $^{\mathrm{c}}$ \\
\hline
\end{tabular}

aRecovered $10 \%$ bromide $6 \mathrm{a}$. bRecovered $13 \%$ bromide $6 \mathbf{6}$. cNo reaction. 
Table 2. The effect of different halides on the efficiency of the haloacylsilane cyclization.

\begin{tabular}{ccccccc}
\hline entry & substrate & solvent & KI (equiv) & temp $\left({ }^{\circ} \mathrm{C}\right)$ & time $(\mathrm{h})$ & yield of 7a (\%) \\
\hline 1 & 6b X $=$ Cl & DMF & 0 & 100 & 72 & 39 \\
2 & 6b & DMF & catalytic & 100 & 48 & 53 \\
3 & 6b & NMP & 1 & 100 & 48 & 97 \\
4 & 6b & NMP & 2 & 100 & 16 & 94 \\
5 & 6c X $=$ I & benzene & 0 & 80 & 16 & $22^{\text {a }}$ \\
\hline
\end{tabular}

aRecovered $53 \%$ of $6 c$.

In contrast to the cyclization of bromoacylsilane $6 \mathrm{a}$, chloroacylsilane $\mathbf{6 b}$ (Tablc 2 , entry 1 ) is less reactive. However, in the presence of potassium iodide (entries $2-4$, Table 2 ), the cyclization of $6 \mathbf{b}$ can eventually be accomplished in a reasonably short time with high yield. In fact, iodoacylsilane 6c (entry 5, Table 2) undergoes cyclization even in refluxing benzene albeit in low efficiency.

To prepare dihydrofuran 5 from chloroacylsilane 4, we treated 4 with one equivalent of potassium iodide in NMP at $100^{\circ} \mathrm{C}$ for $12 \mathrm{~h}$ (entry 1, Table 3). Surprisingly, we did not obtain any dihydrofuran 5 (cf. entry 3 , Table 2). With a lower temperature $\left(66^{\circ} \mathrm{C}\right.$ ) and longer time (entry 2$)$, we were able to isolate dihydrofuran 5 in $72 \%$ yield. This indicates that the five-membered ring product may be sensitive to the reaction condition at high temperature, and that lower temperature and shorter reaction time are preferred. Therefore, with the addition of more potassium iodide ( 3 equiv) the reaction was completed in $8 \mathrm{~h}$ at $70^{\circ} \mathrm{C}$ with excellent yield (entry 3 ).

Table 3. Formation of dihydrofuran 5 from the cyclization of chloroacylsilane 4.

\begin{tabular}{cccccc}
\hline entry & solvent & KI (equiv) & temp $\left({ }^{\circ} \mathrm{C}\right)$ & time $(\mathrm{h})$ & yield of $\mathbf{5}(\%)$ \\
\hline 1 & NMP & 1 & 100 & 12 & 0 \\
2 & NMP & 1 & 66 & 30 & 72 \\
3 & NMP & 3 & 70 & 8 & 94 \\
\hline
\end{tabular}

This type of cyclization reaction is not limited to primary halides. As shown in eq 3, the secondary bromide $8^{5 \mathrm{a}}$ cyclized in NMP at $100^{\circ} \mathrm{C}$ for $9.5 \mathrm{~h}$ resulted in an $83 \%$ yield of dihydropyran 9 . The silyl group of the acylsilane can be changed to a presumably labile trimethylsilyl group in chloroacylsilane 10 (eq 4). The cyclization of 10 proceeded in NMP at $90^{\circ} \mathrm{C}(20 \mathrm{~h})$ in the presence of two equivalents of potassium iodide to produce a $71 \%$ yield of dihydropyran $7 \mathbf{b} . .^{14}$

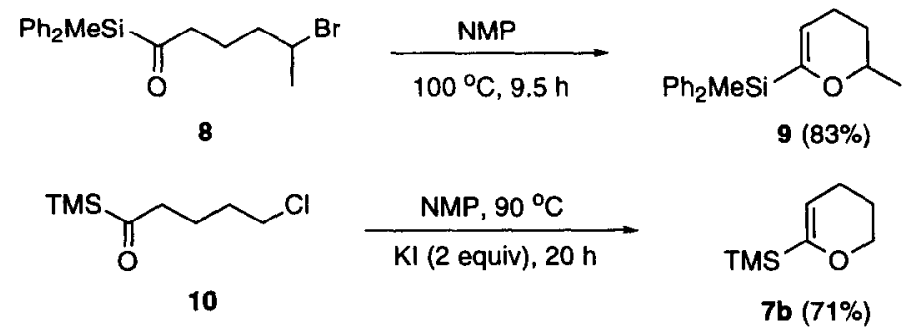




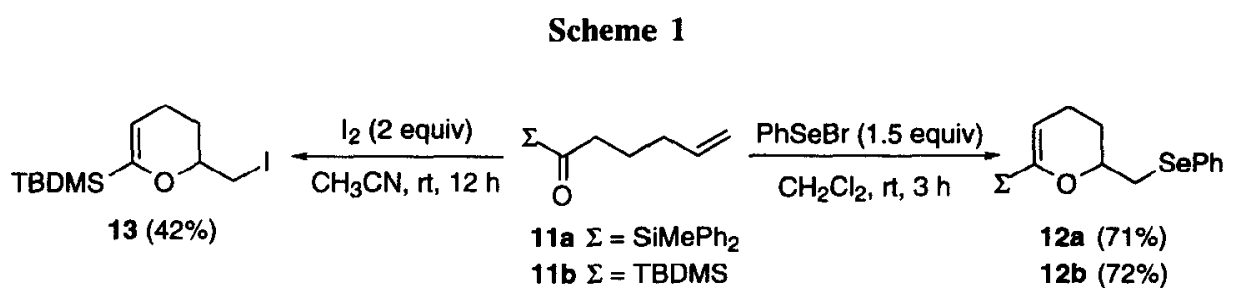

Olefin initiated cyclization is a common strategy used to prepare oxygen-containing heterocycles. ${ }^{15}$ The carbonyl functional groups that participate in these type of reactions include anides, carboxylic acids, and esters. Due to the unusual nucleophilic nature of the carbonyl oxygen of acylsilanes, we also studied the olefin initiated cyclization of unsaturated acylsilanes. The unsaturated acylsilanes can be prepared using the 1,3dithiane strategy developed by Brook and Corey. ${ }^{16,17}$ Indeed, acylsilanes 11a ${ }^{17}$ and $11 \mathbf{b}$ (Scheme 1) reacted with phenylselenenyl bromide ( 1.5 equiv) in dichloromethane at room temperature $(3 \mathrm{~h}$ ) to afford selenides 12a (71\%) and 12b (72\%), respectively. Furthermore, treatment of unsaturated acylsilane 11b with iodine ( 2 equiv) in acetonitrile at room temperature for $12 \mathrm{~h}$ generated cyclized iodide 13 in $42 \%$ yield.

In contrast, the reaction of homologous acylsilane 14 (Scheme 2) with 1.1 equivalent of phenylselenenyl bromide in dichloromethane ( $\mathrm{rt}, 3 \mathrm{~h}$ ) did not produce any cyclized product. When the polar solvent NMP was used (Scheme 2), acylsilane 14 reacted with one equivalent of phenylselenenyl bromide in the presence of triethylamine (1 equiv) at room temperature ( $45 \mathrm{~min}$ ) to give a mixture of monoselenide 15 (14\%), bis-selenide $16(16 \%)$, and acylsilane $17(5 \%)$. Treatment of monoselenide 15 with another equivalent of phenylselenenyl bromide led to the formation of bis-selenide $16 .{ }^{18}$ In principle, bis-selenide 16 may also be originated from further cyclization of acylsilane 17. Therefore, we reacted acylsilane 14 with 2.5 equivalent of phenylselenenyl bromide in NMP at $0^{\circ} \mathrm{C}$, warmed it up to room temperature $(16 \mathrm{~h})$, and obtained $83 \%$ yield of bis-selenide 16. We found that under various conditions it is very difficult to obtain the monoselenide without the formation of the bis-selenide. Iodide 18 can also be prepared ( $58 \%$ ) by reacting acylsilane 14 with excess iodine ( 2.5 equiv) in NMP at $60^{\circ} \mathrm{C}(2 \mathrm{~h})$. Sodium hydrogen phosphate (5 equiv) was used to remove hydrogen iodide. In the iodination reaction, we did not have the problem of over-iodination. In comparison, dihydropyran 12a (Scheme 3) was treated with phenylselenenyl chloride (1 equiv) in dichloromethane to give bis-selenide 19 in

\section{Scheme 2}

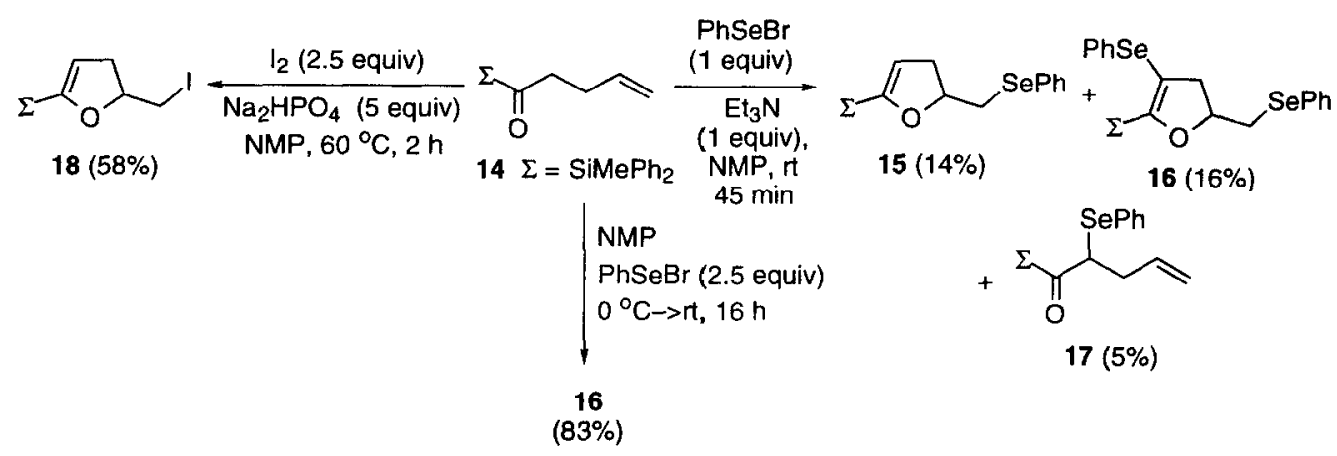




\section{Scheme 3}
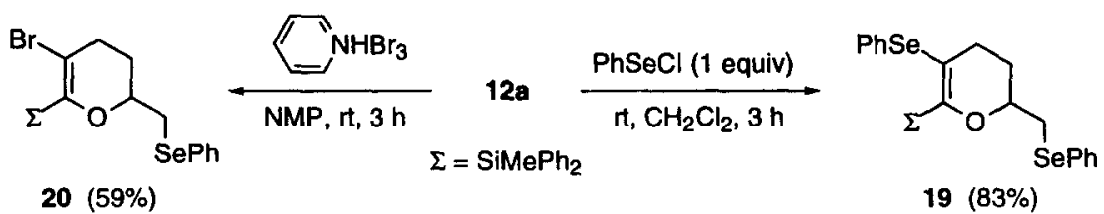

$83 \%$ yield. Bromination is also possible, and the reaction of dihydropyran 12a with pyridinium perbromide in NMP produced a $59 \%$ yield of vinyl bromide $\mathbf{2 0} .19$

In general, the formation of the dihydropyran from the unsaturated acylsilane is easier than dihydrofuran. This difference is probably due to the higher strain endured in the 5 -membered ring formation. The formation of dihydrofuran is best performed in polar solvents such as NMP. However, for phenyl-selenenylation, it is difficult for the five-membered ring system to stop at the monoselenenylation. This also reflects the slower rate of dihydrofuran formation, and other side reactions become competitive. The six-membered ring system can be performed in a less polar solvent, namely dichloromethane, and the mono-selenenylation can be accomplished. In the case of acylsilane 14, 6-endo-trig cyclizations are not observed. This indicates the kinetic nature of the cyclizations. The regioselectivity is also in accordance to the general trend observed in olefine initiated cyclizations. 15,20

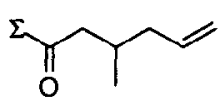

$21 \Sigma=\mathrm{SiMePh}_{2}$<smiles>[3H]C(=O)CCC(C)C=C</smiles>

$23 \Sigma=\mathrm{SiMePh}_{2}$<smiles>[3H]C(=O)CC(C=C)Pc1ccccc1</smiles>
25 $\Sigma=\mathrm{SiMePh}_{2}$
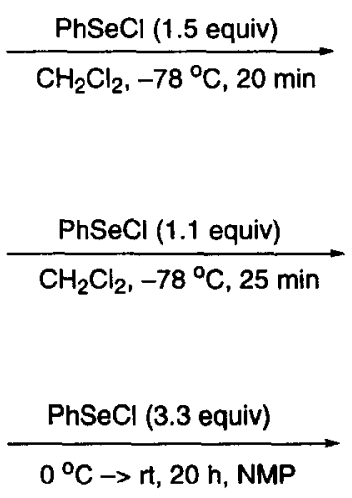

$0^{\circ} \mathrm{C} \rightarrow \mathrm{rt}, 20 \mathrm{~h}, \mathrm{NMP}$<smiles>[Y]C1=CC(C)CC(C[SeH]c2ccccc2)O1</smiles>
$22(88 \%)$<smiles>[Y]C1=CCC(C)C(C[SeH]c2ccccc2)O1</smiles>

$24(62 \%)$<smiles>[Y]C1=C([SeH])C(c2ccccc2)C(C[SeH])O1</smiles>

26 (53\%)

To examine the degree of diastereoselectivity of substituted olefinic acylsilane cyclizations, we studied the cyclizations of acylsilanes 21,23 , and $25^{21}$ (eq 5-7). Both 21 (eq 5) and 23 (eq 6) reacted with phenylselenyl chloride ( 1.1 equiv) in dichloromethane at $-78{ }^{\circ} \mathrm{C}$ and formed dihydropyran selenides $22(88 \%)$ and $24(62 \%)$ as $1: 1$ and 2.2:1 diastereomeric mixtures, respectively. When the cyclization of acylsilane 21 was performed at room temperature, the isomeric ratio of dihydropyran 22 did not change. The cyclization of acylsilane 25 , carried out in NMP with 3.3 equivalents of phenylselenyl chloride (eq 7), gave dihydrofuran 26 in $53 \%$ yield as a 2:1 mixture of cis/trans isomers. We did not determine which isomer is the major one. Comparing with the 
phenylselenolactonization, 3-phenyl-4-pentenoic acid (27) was reported to give cis- and trans-lactone 28 (eq 8) in a ratio of $1: 2.7$, respectively. $20 \mathrm{c}$ Similarly, the analogous 6-membered ring lactone formation also showed low diastereoselectivity. 22,23 The unsaturated acylsilane cyclizations do not provide better stereocontrol than the corresponding phenylselenolactonization of unsaturated acids.<smiles>C=CC(CC(=O)O)Pc1ccccc1</smiles>

27

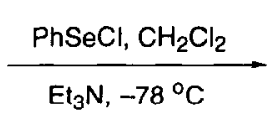

$54 \%$

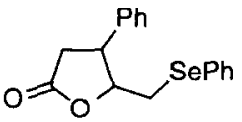

28
$(8)^{20 c}$

In summary. bromo-substituted acylsilanes easily undergo cyclizations when heat in a polar solvent such as NMP to afford 2-silyldihydrofurans and 2-silyldihydropyrans. The cyclizations of chloroacylsilanes are slower; however, the efficiency of the cyclizations can be enhanced by the addition of potassium iodide. Unsaturated acylsilanes undergo cyclizations in the presence of iodine, phenylselenenyl bromide, or chloride. When there is a substituent at the $\beta$ - or $\gamma$-position, the cyclizations of unsaturated acylsilanes give very little diastereoselectivity. Further reactions of the cyclized products with pyridinium perbromide, phenylselenenyl bromide, or chloride are possible. Through this method, highly functionalized dihydrofurans and dihydropyrans can be prepared.

\section{EXPERIMENTAL SECTION}

${ }^{1} \mathrm{H}$ NMR spectra were recorded at 200 or $300 \mathrm{MHz} ;{ }^{13} \mathrm{C}$ NMR spectra were recorded at 50 or $75 \mathrm{MHz}$. Tetramethysilane $(\delta=0 \mathrm{ppm})$ or $\mathrm{CHCl}_{3}(\delta=7.24 \mathrm{ppm})$ were used as internal standards and $\mathrm{CDCl}_{3}$ was used as the solvent. Benzene and THF were distilled from sodium benzophenone ketyl under $\mathrm{N}_{2}$. Dimethylformamide (DMF), $N$-methylpyrrolidone (NMP), and acetonitrile were dried over calcium hydride. Acetone was distilled over sodium carbonate. All reactions were performed under a blanket of $\mathrm{N}_{2}$ or $\mathrm{Ar}$.

5-Chloro-1-(methyldiphenylsilyl)pentan-1-one (6b). To a solution of $340 \mathrm{mg}$ of 2-methyldiphenylsilyl-1,3-dithiane ${ }^{5 a}(1.1 \mathrm{mmol})$ in $1.0 \mathrm{~mL}$ of THF cooled in an ice-water bath was added dropwise over $6 \mathrm{~min}$ $1.0 \mathrm{~mL}$ of a $1.49 \mathrm{M}$ solution of $n$-butyllithium in hexane $(1.5 \mathrm{mmol})$. After stirring for another $30 \mathrm{~min}$ at $0{ }^{\circ} \mathrm{C}$, the resulting solution was cooled in a dry ice-acetonitrile bath followed by the addition of $0.16 \mathrm{~mL}(1.6 \mathrm{mmol})$ of 1-bromo-3-chloropropane in one portion. The resulting mixture was stirred at the same temperature for $1 \mathrm{~h}$ and then partitioned between $30 \mathrm{~mL}$ of ether and $20 \mathrm{~mL}$ of water. The organic layer was washed with $20 \mathrm{~mL}$ of brine, dried $\left(\mathrm{MgSO}_{4}\right)$ and concentrated in vacuo. The residual oil was dissolved in $7 \mathrm{~mL}$ of wet THF (15\%) followed by the addition of $350 \mathrm{mg}(1.6 \mathrm{mmol})$ of red mercuric oxide, $210 \mathrm{mg}$ of Celite, and $0.20 \mathrm{~mL}$ ( 1.6 $\mathrm{mmol}$ ) of borontrifluoride etherate. The resulting mixture was stirred at room temperature for $2 \mathrm{~h}$, diluted with ether $(50 \mathrm{~mL})$ and filtered. The filtrate was washed with brine $(10 \mathrm{~mL})$, dried $\left(\mathrm{MgSO}_{4}\right)$ and concentrated in vacuo. The residual oil was chromatographed over silica gel (eluted with hexane/ethyl acetate $=98 / 2$ ) to give $252 \mathrm{mg}(77 \%)$ of $6 \mathbf{b}$ as a pale yellow oil: IR (neat) $1640 \mathrm{~cm}^{-1}$; ${ }^{1} \mathrm{H} \mathrm{NMR}(200 \mathrm{MHz}) \delta 0.75\left(\mathrm{~s}, 3 \mathrm{H}, \mathrm{SiCH}_{3}\right)$, 1.55-1.75 (m, $4 \mathrm{H}$ ), 2.68 (br t, $J=7 \mathrm{~Hz}, 2 \mathrm{H}, \mathrm{COCH}_{2}$ ), 3.40 (br t, $J=7 \mathrm{~Hz}, 2 \mathrm{H}, \mathrm{ClCH}_{2}$ ), 7.25-7.50 (m, 6 H), 7.50-7.68 (m, 4 H); ${ }^{3} \mathrm{C}$ NMR (50 MHz) $\delta-5.5,19.4,31.8,44.5,48.4,128.1,130.1,132.5,134.9$, 243.6; mass spectrum, $m / z$ (relative intensity) $315\left(\mathrm{M}^{+}-1,3\right), 225$ (25), 197 (100), 181 (15), 105 (20), 85 (30). Anal. Calcd for $\mathrm{C}_{18} \mathrm{H}_{21} \mathrm{ClOSi}: \mathrm{C}, 68.22 ; \mathrm{H}, 6.68$. Found: $\mathrm{C}, 68.50 ; \mathrm{H}, 5.93$. 
5-lodo-1-(methyldiphenylsilyl)pentan-1-one (6c). A solution of $90.0 \mathrm{mg}(0.28 \mathrm{mmol})$ of $6 \mathrm{~b}$ and 60 $\mathrm{mg}(0.40 \mathrm{mmol})$ of sodium iodide in $2 \mathrm{~mL}$ of acetone was stirred under argon at $60^{\circ} \mathrm{C}$ for $2 \mathrm{~h}$. The resulting mixture was diluted with ether and filtered. The filtrate was concentrated in vacuo to give $101 \mathrm{mg}(89 \%)$ of crude $6 \mathrm{c}$ as a yellow oil. This material will decompose through silica gel column chromatography and was used directly for the cyclization. IR (neat) $1640 \mathrm{~cm}^{-1} ;{ }^{1} \mathrm{H}$ NMR $(200 \mathrm{MHz}) \delta 0.75\left(\mathrm{~s}, 3 \mathrm{H}, \mathrm{SiCH}_{3}\right), 1.50$ $1.75(\mathrm{~m}, 4 \mathrm{H}), 2.66\left(\mathrm{t}, J=7 \mathrm{~Hz}, 2 \mathrm{H}, \mathrm{COCH}_{2}\right), 3.04\left(\mathrm{t}, J=7 \mathrm{~Hz}, 2 \mathrm{H}, \mathrm{ICH}_{2}\right), 7.30-7.50(\mathrm{~m}, 6 \mathrm{H}), 7.50$ $7.63(\mathrm{~m}, 4 \mathrm{H}) ;{ }^{13} \mathrm{C} \mathrm{NMR}(50 \mathrm{MHz}) \delta-5.4,6.2,23.0,32.8,48.1,128.2,130.1,132.4,134.9,243.6$.

5-Chloro-1-(trimethylsilyl)pentan-1-one (10). According to the procedure for the preparation of $6 \mathrm{~b}$, we prepared 10 (84\%) as a pale yellow oil: IR (neat) $1639 \mathrm{~cm}^{-1}$; ${ }^{1} \mathrm{H} \mathrm{NMR}(200 \mathrm{MHz}) \delta 0.20\left(\mathrm{~s}, 9 \mathrm{H}, \mathrm{CH}_{3}\right)$, 1.55-1.85 (m, $4 \mathrm{H}), 2.64\left(\mathrm{t}, J=7 \mathrm{~Hz}, 2 \mathrm{H}, \mathrm{COCH}_{2}\right), 3.52\left(\mathrm{t}, J=6 \mathrm{~Hz}, 2 \mathrm{H}, \mathrm{ClCH}_{2}\right) ;{ }^{13} \mathrm{C} \operatorname{NMR}(50 \mathrm{MHz}) \delta$ $-3.4,19.2,31.9,44.5,47.1,247.2$; mass spectrum, $m / z$ (relative intensity) $193\left(\mathrm{M}^{+}, 10\right), 119(5), 93(20)$, 73 (100), 55 (30); HRMS calcd for $\mathrm{C}_{8} \mathrm{H}_{18}{ }^{35} \mathrm{ClOSi} \mathrm{m} / z$ 193.0815, found 193.0771 .

General procedure for the cyclizations of haloacylsilanes. The haloacylsilane $(1 \mathrm{mmol})$ was dissolved in $10 \mathrm{~mL}$ of dried NMP and heated with the reagents at the temperature and time indicated in Tables $1-3$ and eq 3,4 . The resulting solution was partitioned between $50 \mathrm{~mL}$ of ether and $50 \mathrm{~mL}$ of water. The ether layer was washed with brine $(20 \mathrm{~mL})$, dried $\left(\mathrm{MgSO}_{4}\right)$, and concentrated in vacuo. The residue was chromatographed over silica gel column chromatography (eluted with suitable ethyl acetate/hexane pair) to give the desired product.

5-Methyldiphenylsilyl-2,3-dihydrofuran (5). IR (neat) $1590 \mathrm{~cm}^{-1} ;{ }^{1} \mathrm{H}$ NMR (200 MHz) $80.69(\mathrm{~s}, 3$ $\mathrm{H}, \mathrm{SiCH}_{3}$ ), 2.63 (td, $J=10,2 \mathrm{~Hz}, 2 \mathrm{H}$, allyl), $4.36\left(\mathrm{t}, J=10 \mathrm{~Hz}, 2 \mathrm{H}, \mathrm{OCH}_{2}\right), 5.30(\mathrm{t}, J=2 \mathrm{~Hz}, 1 \mathrm{H}$, $=\mathrm{CH}), 7.25-7.50(\mathrm{~m}, 6 \mathrm{H}), 7.50-7.70(\mathrm{~m}, 4 \mathrm{H}) ;{ }^{13} \mathrm{C} \mathrm{NMR}(50 \mathrm{MHz}) \delta-4.6,30.7,70.8,115.4,127.8$, 129.6, 134.4, 134.9, 159.0. Anal. Calcd for $\mathrm{C}_{17} \mathrm{H}_{18} \mathrm{OSi}$ : C, 76.64; $\mathrm{H}, 6.81$. Found: $\mathrm{C}, 76.92 ; \mathrm{H}, 6.89$.

6-Methyldiphenylsilyl-3,4-dihydro-2H-pyran (7a). IR (neat) $1611 \mathrm{~cm}^{-1} ;{ }^{1} \mathrm{H}$ NMR (200 MHz) $\delta 0.62$ (s, $3 \mathrm{H}, \mathrm{SiCH}_{3}$ ), 1.87 (quintet, $J=5 \mathrm{~Hz}, 2 \mathrm{H}$ ), 2.03 (q, $J=5 \mathrm{~Hz}, 2 \mathrm{H}$, allyl), 3.95 (t, $J=5 \mathrm{~Hz}, 2 \mathrm{H}, \mathrm{OCH}$ ), $5.05(\mathrm{t}, J=5 \mathrm{~Hz}, 1 \mathrm{H},=\mathrm{CH}), 7.20-7.40(\mathrm{~m}, 6 \mathrm{H}), 7.50-7.65(\mathrm{~m}, 4 \mathrm{H}) ;{ }^{13} \mathrm{C} \mathrm{NMR}(50 \mathrm{MHz}) \delta-4.9,20.9$, $22.6,65.7,114.9,127.7,129.3,135.0,135.3,157.0$; mass spectrum, $m / z$ (relative intensity) $280\left(\mathrm{M}^{+}, 30\right)$, 197 (100), 180 (25), 137 (40), 105 (50), 53 (40); HRMS calcd for $\mathrm{C}_{18} \mathrm{H}_{20} \mathrm{OSi} \mathrm{m} / \mathrm{z} 280.1284$, found 280.1283 .

2-Methyl-6-methyldiphenylsilyl-3,4-dihydro-2H-pyran (9). IR (neat) $1611 \mathrm{~cm}^{-1} ;{ }^{1} \mathrm{H}$ NMR (200 $\mathrm{MHz}) \delta 0.62$ (s, $\left.3 \mathrm{H}, \mathrm{SiMe}_{3}\right), 1.26\left(\mathrm{~d}, J=7 \mathrm{~Hz}, 3 \mathrm{II}, \mathrm{O}-\mathrm{C}_{-} \mathrm{CH}_{3}\right), 1.50-1.69(\mathrm{~m}, 2 \mathrm{H}), 1.75-2.16(\mathrm{~m}, 2 \mathrm{H})$, $3.85-4.01(\mathrm{~m}, 1 \mathrm{H}, \mathrm{OCH}), 5.02(\mathrm{t}, J=4 \mathrm{~Hz}, \mathrm{I} \mathrm{H},=\mathrm{CH}), 7.28-7.50(\mathrm{~m}, 6 \mathrm{H}), 7.50-7.69(\mathrm{~m}, 4 \mathrm{H}) ;{ }^{13} \mathrm{C}$ NMR $(50 \mathrm{MHz}) \delta-4.9,21.1,29.3,29.7,71.0,114.1,127.6,129.2,134.0,135.1,135.7,156.6$; mass spectrum, $m / z$ (relative intensity) $294\left(\mathrm{M}^{+}, 100\right), 279$ (6), 251 (18), 237 (9), $215(8), 197(98), 156(38), 137$ (75); HRMS calcd for $\mathrm{C}_{19} \mathrm{H}_{22} \mathrm{OSi} \mathrm{m} / \mathrm{z} 294.1441$, found 294.1435 . 
General procedure for the preparation of unsaturated acylsilanes. To a solution of the 2-silyl1,3-dithiane (3.0 mmol) in $3.0 \mathrm{~mL}$ of THF cooled in an ice-water bath was added dropwise over $5 \mathrm{~min} 2.4 \mathrm{~mL}$ of a $1.50 \mathrm{M}$ solution of $n$-butyllithium in hexane $(3.6 \mathrm{mmol})$. After stirring for another $30 \mathrm{~min}$ at $0^{\circ} \mathrm{C}$, the unsaturated bromide $(3.6 \mathrm{mmol})$ was added dropwise over $5 \mathrm{~min}$. The resulting mixture was stirred at the same temperature for $1 \mathrm{~h}$ and then partitioned between $50 \mathrm{~mL}$ of ether and $20 \mathrm{~mL}$ of water. The organic layer was washed with $20 \mathrm{~mL}$ of brine, dried $\left(\mathrm{MgSO}_{4}\right)$, and concentrated in vacuo. The residue was mixed with $800 \mathrm{mg}$ of Celite, and $500 \mathrm{mg}$ of sodium bicarbonate in $7 \mathrm{~mL}$ of acetonitrile/water ( $3 / 1$ by volume) and cooled in an dry ice-carbon tetrachloride bath. A solution of ceric ammonium nitrate $(12 \mathrm{mmol})$ in $12 \mathrm{~mL}$ of acetonitrile/water ( $3 / 1$ by volume) was added over $3 \mathrm{~min}$ to the above mentioned mixture. The resulting mixture was stirred at the same temperature for another $3 \mathrm{~min}$, diluted with $20 \mathrm{~mL}$ of ether, and filtered. The filtrate was washed with 10 $\mathrm{mL}$ of water, $10 \mathrm{~mL}$ of brine, dried $\left(\mathrm{MgSO}_{4}\right)$, and concentrated in vacuo. The residue was chromatographed over silica gel column chromatography (eluted with suitable ethyl acetate/hexane pair) to give the unsaturated acylsilane.

1-t-Butyldimethylsilyl-5-hexen-1-one (11b). According to the general procedure, the reaction of 2-tbutyldimethylsilyl-1,3-dithiane with 5-bromopentene gave $64 \%$ of $11 \mathrm{~b}$ as a pale yellow oil: IR (neat) $1637 \mathrm{~cm}^{-}$ '; ${ }^{1} \mathrm{H}$ NMR (300 MHz) $\delta 0.13\left(\mathrm{~s}, 6 \mathrm{H}, \mathrm{SiCH}_{3}\right), 0.89$ (s, $9 \mathrm{H}, t$-butyl), 1.57 (quintet, $J=7 \mathrm{~Hz}, 2 \mathrm{H}, \mathrm{CO}-\mathrm{C}$ $\mathrm{CH}_{2}$ ), 1.97 (quartet, $J=7 \mathrm{~Hz}, 2 \mathrm{H}$, allyl), $2.56\left(\mathrm{t}, J=7 \mathrm{~Hz}, 2 \mathrm{H}, \mathrm{COCH}_{2}\right), 4.88-5.00\left(\mathrm{~m}, 2 \mathrm{H},=\mathrm{CH}_{2}\right), 5.71$ (ddt, $J=17,10,7 \mathrm{~Hz}, 2 \mathrm{H}, \mathrm{CH}=$ ); ${ }^{13} \mathrm{C}$ NMR $(75 \mathrm{MHz}) \delta-7.0,16.4,20.9,26.4,33.1,49.3,115.0,138.2$, 246.5; mass spectrum, $m / z$ (relative intensity) $211\left(\mathrm{M}^{+}-1,5\right), 159(24), 147(19), 115(50), 91$ (20), 75 (59), 73 (100), 69 (8); HRMS calcd for $\mathrm{C}_{12} \mathrm{H}_{23} \mathrm{OSi}\left(\mathrm{M}^{+-1}\right) \mathrm{m} / \mathrm{z} 211.1513$, found 211.1494 .

1-Methyldiphenylsilyl-4-penten-1-one (14). According to the general procedure, the reaction of 2methyldiphenylsilyl-1,3-dithiane ${ }^{5 a}$ with 4-bromobutene gave $57 \%$ of 14 as a pale yellow oil: IR (neat) 1637 $\mathrm{cm}^{-1}$; ${ }^{1} \mathrm{H}$ NMR $(300 \mathrm{MHz}) \delta 0.77\left(\mathrm{~s}, 3 \mathrm{H}, \mathrm{SiCH}_{3}\right), 2.23(\mathrm{q}, J=7 \mathrm{~Hz}, 2 \mathrm{H}$, allyl), $2.77(\mathrm{t}, J=7 \mathrm{~Hz}, 2 \mathrm{H}$, $\left.\mathrm{COCH}_{2}\right), 4.86-4.98\left(\mathrm{~m}, 2 \mathrm{H},=\mathrm{CH}_{2}\right), 5.72(\mathrm{ddt}, J=17,10,7 \mathrm{~Hz}, 1 \mathrm{H}, \mathrm{CH}=), 7.36-7.45(\mathrm{~m}, 6 \mathrm{H}), 7.56-$ $7.63(\mathrm{~m}, 4 \mathrm{H}) ;{ }^{13} \mathrm{C}$ NMR $(50 \mathrm{MHz}) \delta-5.4,26.1,48.7,114.9,128.2,130.1,132.5,134.9,137.3,243.3$; mass spectrum, $m / z$ (relative intensity) $279\left(\mathrm{M}^{+}-1,2\right), 265$ (2), 251 (5), 238 (6), 225 (30), 197 (100), 142 (7), 137 (27); HRMS calcd for $\mathrm{C}_{18} \mathrm{H}_{20} \mathrm{OSi} \mathrm{m} / \mathrm{z} 280.1284$, found 280.1273.

3-Methyl-1-methyldiphenylsilyl-5-hexen-1-one (21). According to the general procedure, the reaction of 2-methyldiphenylsilyl-1,3-dithiane ${ }^{5 a}$ with 5-bromo-4-methylpentene ${ }^{24}$ gave $51 \%$ of 21 as a pale yellow oil: IR (neat) $1639 \mathrm{~cm}^{-1}$; ${ }^{1} \mathrm{H}$ NMR $(300 \mathrm{MHz}) \delta 0.72\left(\mathrm{~s}, 3 \mathrm{H}, \mathrm{SiCH}_{3}\right), 0.76\left(\mathrm{~d}, J=7 \mathrm{~Hz}, 3 \mathrm{H}, \mathrm{CH}_{3}\right), 1.70-1.95$ (m, $2 \mathrm{H}$, allyl), 2.10 (octet, $J=7 \mathrm{~Hz}, 1 \mathrm{H}, \mathrm{CHMe}$ ), 2.44 (dd, $J=17,7 \mathrm{~Hz}, 1 \mathrm{H}, \mathrm{COCH}_{2}$ ), 2.65 (dd, $J=17$, $\left.7 \mathrm{~Hz}, 1 \mathrm{H}, \mathrm{COCH}_{2}\right), 4.84-4.95\left(\mathrm{~m}, 2 \mathrm{H},=\mathrm{CH}_{2}\right), 5.58$ (ddt, $\left.J=17,10,7 \mathrm{~Hz}, 1 \mathrm{H}, \mathrm{CH}=\right), 7.24-7.47(\mathrm{~m}, 6$ $\mathrm{H}), 7.47-7.65(\mathrm{~m}, 4 \mathrm{H}) ;{ }^{13} \mathrm{C}$ NMR $(75 \mathrm{MHz}) \delta-5.3,19.8,27.3,41.1,56.2,116.2,128.2,130.1,132.8$, 135.0, 136.7, 244.7; mass spectrum, $m / z$ (relative intensity) $308\left(\mathrm{M}^{+}, 1\right), 197$ (100), 137 (32); HRMS calcd for $\mathrm{C}_{20} \mathrm{H}_{24} \mathrm{OSi} \mathrm{m} / \mathrm{z} 308.1596$, found 308.1586 .

4-Methyl-1-methyldiphenylsilyl-5-hexen-1-one (23). According to the general procedure, the reaction of 2-methyldiphenylsilyl-1,3-dithiane ${ }^{5 a}$ with 5-bromo-3-methylpentene ${ }^{25}$ gave $48 \%$ of 23 as a pale yellow oil: 
IR (neat) $1620 \mathrm{~cm}^{-1} ;{ }_{1}^{1} \mathrm{H}$ NMR ( $\left.300 \mathrm{MHz}\right) \delta 0.73\left(\mathrm{~s}, 3 \mathrm{H}, \mathrm{SiCH}_{3}\right), 0.88\left(\mathrm{~d}, J=7 \mathrm{~Hz}, 3 \mathrm{H}, \mathrm{CH}_{3}\right), 1.32-1.60$ $(\mathrm{m}, 2 \mathrm{H}), 1.97$ (septet, $J=7.5 \mathrm{~Hz}, 1 \mathrm{H}$, allyl), $2.62\left(\mathrm{t}, J=7.5 \mathrm{~Hz}, 2 \mathrm{H}, \mathrm{COCH}_{2}\right), 4.72-4.88(\mathrm{~m}, 2 \mathrm{H}$, $\left.=\mathrm{CH}_{2}\right), 5.49(\mathrm{dt}, J=15,7.5 \mathrm{~Hz}, 1 \mathrm{H}, \mathrm{CH}=), 7.30-7.45(\mathrm{~m}, 6 \mathrm{H}), 7.51-7.59(\mathrm{~m}, 4 \mathrm{H}) ;{ }^{3} \mathrm{C}$ NMR $(50 \mathrm{MHz})$ $\delta-5.3,20.2,28.5,37.4,47.4,113.2,127.5,128.0,128.2,130.0,132.9,135.0,143.8,244.4$; mass spectrum, $m / z$ (relative intensity) $308\left(\mathbf{M}^{+}, 9\right), 293$ (20), 266 (18), 231 (19), 197 (100), 170 (19), 137 (28); HRMS calcd for $\mathrm{C}_{20} \mathrm{H}_{24} \mathrm{OSi} \mathrm{m} / \mathrm{z} 308.1596$, found 308.1604 .

6-Methyldiphenylsilyl-2-phenylselenenylmethyl-3,4-dihydro-2H-pyran (12a). A solution of $70 \mathrm{mg}$ $(0.24 \mathrm{mmol})$ of $11 \mathrm{a}$ and $83 \mathrm{mg}(0.36 \mathrm{mmol})$ of phenylselenenyl bromide in $1.5 \mathrm{~mL}$ of dichloromethane was stirred at room temperature for $3 \mathrm{~h}$ and then partitioned between $20 \mathrm{~mL}$ of ether and $20 \mathrm{~mL}$ of water. The organic laycr was washed with $10 \mathrm{~mL}$ of brine, dried $\left(\mathrm{MgSO}_{4}\right)$, and concentrated in vacuo. The residual oil was chromatographed over silica gel (eluted with dichloromethane/hexane $=15 / 85$ ) to give $76 \mathrm{mg}(71 \%)$ of 12a as a pale yellow liquid: IR (neat) $1610 \mathrm{~cm}^{-1}$; ${ }^{1} \mathrm{H}$ NMR (300 MHz) $\delta 0.61\left(\mathrm{~s}, 3 \mathrm{H}, \mathrm{SiCH}_{3}\right), 1.62-1.83(\mathrm{~m}, 1$ H), 1.91-2.18 (m, $3 \mathrm{H}), 3.02$ (dd, $J=12.4,6.6 \mathrm{~Hz}, 1 \mathrm{H}, \mathrm{SeCH}$ ), 3.17 (dd, $J=12.4,6.2 \mathrm{~Hz}, 1 \mathrm{H}, \mathrm{SeCH}$ ), 3.93-4.05 (m, $1 \mathrm{H}, \mathrm{OCH}$ ), 5.03 (br s, $1 \mathrm{H},=\mathrm{CH}$ ), 7.12-7.24 (m, $3 \mathrm{H}), 7.30-7.42(\mathrm{~m}, 6 \mathrm{H}), 7.42-7.48$ (m, $2 \mathrm{H}), 7.56-7.60(\mathrm{~m}, 4 \mathrm{H}) ;{ }^{13} \mathrm{C}$ NMR $(75 \mathrm{MHz}) \delta-4.9,20.8,27.0,32.4,74.2,114.5,126.6,127.7,130.0$, 132.3, 135.1, 156.6; mass spectrum, $m / z$ (relative intensity) $250\left(\mathrm{M}^{+}, 29\right), 293(47), 197(100), 137$ (28); HRMS calcd for $\mathrm{C}_{25} \mathrm{H}_{26} \mathrm{OSeSi} \mathrm{m} / \mathrm{z} 450.0928$, found 450.0920 .

6-t-Butyldimethylsilyl-2-phenylselenenylmethyl-3,4-dihydro-2H-pyran (12b). According to the procedure for the preparation of 12a, the reaction of $119 \mathrm{mg}(0.56 \mathrm{mmol})$ of $11 \mathrm{~b}$ and $198 \mathrm{mg}(0.84 \mathrm{mmol})$ phenylselenenyl bromide gave $149 \mathrm{mg}(72 \%)$ of $\mathbf{1 2 b}$ as a pale yellow oil: IR (neat) $1612 \mathrm{~cm}^{-1} ;{ }^{1} \mathrm{H}$ NMR (200 $\mathrm{MHz}) \delta 0.02\left(\mathrm{~s}, 6 \mathrm{H}, \mathrm{SiCH}_{3}\right), 0.90(\mathrm{~s}, 9 \mathrm{H}, t-\mathrm{Bu}), 1.55-1.75(\mathrm{~m}, 1 \mathrm{H}), 1.85-2.15(\mathrm{~m}, 3 \mathrm{H}), 2.99$ (dd, $J=$ $12,6 \mathrm{~Hz}, 1 \mathrm{H}, \mathrm{SeCH}$ ), 3.17 (dd, $J=12,6 \mathrm{~Hz}, 1 \mathrm{H}, \mathrm{SeCH}$ ), 3.83-3.95 (m, $1 \mathrm{H}, \mathrm{OCH}), 4.94$ (br t, $J=4 \mathrm{~Hz}$, $1 \mathrm{H},=\mathrm{CH}), 7.15-7.28(\mathrm{~m}, 3 \mathrm{H}), 7.45-7.52(\mathrm{~m}, 1 \mathrm{H}), 7.55-7.65(\mathrm{~m}, 1 \mathrm{H}) ;{ }^{13} \mathrm{C}$ NMR $(50 \mathrm{MHz}) \delta-7.0$, $16.5,20.7,26.7,27.3,32.7,73.7,111.4,126.6,127.7,129.0,129.2,131.4,132.1,158.5$; mass spectrum, $\mathrm{m} / \mathrm{z}$ (relative intensity) $368\left(\mathrm{M}^{+}, 18\right), 311$ (100), 234 (15), 215 (93), 195 (6), 157 (30), 115 (13), 73 (97), 59 (23); HRMS calcd for $\mathrm{C}_{18} \mathrm{H}_{28} \mathrm{OSeSi} \mathrm{m} / z$ 368.1074, found 368.1069 .

6-t-Butyldimethylsilyl-2-iodomethyl-3,4-dihydro-2H-pyran (13). To a solution of $106 \mathrm{mg}(0.50$ $\mathrm{mmol}$ ) of $11 \mathrm{~b}$ in $2.5 \mathrm{~mL}$ of acetonitrile at room temperature was added over $5 \mathrm{~min}$ a solution of $254 \mathrm{mg}$ ( 1.0 mmol) of iodine in $2 \mathrm{~mL}$ of acetonitrile. The resulting solution was stirred for another $12 \mathrm{~h}$ and partitioned between $10 \mathrm{~mL}$ of ether and $10 \mathrm{~mL}$ of water. The ether layer was washed with $10 \mathrm{~mL}$ of sat. sodium thiosulfate aqueous solution, dried $\left(\mathrm{MgSO}_{4}\right)$, and concentrated in vacuo. The residue was chromatographed over silica gel (eluted with ethyl acetate/hexane $=2 / 98$ ) to give $66 \mathrm{mg}(42 \%)$ of 13 as a pale yellow oil: IR (neat) $1615 \mathrm{~cm}^{-1} ;{ }^{1} \mathrm{H}$ NMR $(200 \mathrm{MHz}) \delta 0.25\left(\mathrm{~s}, 6 \mathrm{H}, \mathrm{SiCH}_{3}\right), 0.90(\mathrm{~s}, 9 \mathrm{H}, t-\mathrm{Bu}), 1.56-1.73(\mathrm{~m}, 1 \mathrm{H})$, 1.85-2.15 (m, $3 \mathrm{H}), 3.23(\mathrm{~d}, J=6 \mathrm{~Hz}, 2 \mathrm{H}, \mathrm{ICH}), 3.66-3.77(\mathrm{~m}, 1 \mathrm{H}, \mathrm{OCH}), 4.90-4.98(\mathrm{~m}, 1 \mathrm{H},=\mathrm{CH})$; ${ }^{13} \mathrm{C}$ NMR $(50 \mathrm{MHz}) \delta-7.0,9.1,16.5,20.3,26.8,27.3,73.4,111.2,158.4$; mass spectrum, $\mathrm{m} / \mathrm{z}$ (relative intensity) $338\left(\mathrm{M}^{+}, 11\right), 281$ (76), 211 (8), 185 (100), 153 (28), 79 (13), 75 (90), 59 (21), 43 (17); HRMS calcd for $\mathrm{C}_{12} \mathrm{H}_{24} \mathrm{IOSi}\left(\mathrm{M}^{+}+1\right) \mathrm{m} / \mathrm{z} 339.0643$, found 339.0683 . 
5-Methyldiphenylsilyl-4-phenylselenenyl-2-phenylselenenylmethyl-2,3-dihydrofuran (16). To a solution of $200 \mathrm{mg}(0.71 \mathrm{mmol})$ of $14 \mathrm{in} 3 \mathrm{~mL}$ of NMP cooled in an ice-water bath was added $419 \mathrm{mg}$ (1.80 $\mathrm{mmol}$ ) of phenylselenenyl bromide in one portion. The resulting solution was stirred at room temperature for $16 \mathrm{~h}$ and partitioned between $25 \mathrm{~mL}$ of ether and $25 \mathrm{~mL}$ of water. The ether layer was washed with $10 \mathrm{~mL}$ of brine, dried $\left(\mathrm{MgSO}_{4}\right)$, and concentrated in vacuo. The residue was chromatographed over silica gel (eluted with ethyl acetate/hexane $=4 / 96$ ) to give $348 \mathrm{mg}(83 \%)$ of 16 as a yellow oil: IR (neat) $1573 \mathrm{~cm}^{-1}$; ${ }^{1} \mathrm{H}$ NMR (300 MHz) $\delta 0.83\left(\mathrm{~s}, 3 \mathrm{H}, \mathrm{SiCH}_{3}\right.$ ), 2.62 (dd, $J=15.8,7.0 \mathrm{~Hz}, 1 \mathrm{H}$, allyl), 2.94 (dd, $J=15.8,10.1 \mathrm{~Hz}, 1 \mathrm{H}$, allyl), $3.03(\mathrm{~d}, J=12.3 \mathrm{~Hz}, 1 \mathrm{H}, \mathrm{SeCH}), 3.22(\mathrm{dd}, J=12.3,5.0 \mathrm{~Hz}, 1 \mathrm{H}, \mathrm{SeCH}), 4.75-4.87(\mathrm{~m}, 1 \mathrm{H}$, $\mathrm{OCH}), 7.10-7.27(\mathrm{~m}, 8 \mathrm{H}), 7.28-7.58(\mathrm{~m}, 8 \mathrm{H}), 7.57-7.63(\mathrm{~m}, 4 \mathrm{H}) ;{ }^{13} \mathrm{C}$ NMR (50 MHz) 8-3.0, 33.0, $42.7,81.5,114.0,126.4,127.1,127.8,129.0,129.6,130.7,133.0,134.7,135.1$; mass spectrum, $\mathrm{m} / \mathrm{z}$ (relative intensity) $591\left(\mathrm{M}^{+}-1,12\right), 590$ (12), 197 (100); HRMS calcd for $\mathrm{C}_{30} \mathrm{H}_{28} \mathrm{OSe}_{2} \mathrm{Si} m / z$ 592.0240, found 592.0220 .

2-Iodomethyl-5-methyldiphenylsilyl-2,3-dihydrofuran (18). A mixture of $50 \mathrm{mg}(0.18 \mathrm{mmol})$ of 14 , $115 \mathrm{mg}(0.45 \mathrm{mmol})$ of iodine, and $130 \mathrm{mg}(0.92 \mathrm{mmol})$ of sodium hydrogen phosphate in $1.5 \mathrm{~mL}$ of NMP was heated at $60^{\circ} \mathrm{C}$ for $2 \mathrm{~h}$. The resulting mixture was partitioned between $25 \mathrm{~mL}$ of ether and $25 \mathrm{~mL}$ of sat. sodium thiosulfate aqueous solution. The ether layer was dried $\left(\mathrm{MgSO}_{4}\right)$, and concentrated in vacuo. The residue was chromatographed over silica gel (eluted with dichloromethane/hexane $=1 / 4)$ to give $42 \mathrm{mg}(58 \%)$ of 18 as a yellow oil: IR (neat) $1594 \mathrm{~cm}^{-1}$; $1 \mathrm{H} \mathrm{NMR}(200 \mathrm{MHz}) \delta 0.69\left(\mathrm{~s}, 3 \mathrm{H}, \mathrm{SiCH}_{3}\right), 2.48$ (ddd, $J=16.0$, $6.5,2.5 \mathrm{~Hz}, 1 \mathrm{H}$, allyl), 2.83 (ddd, $J=16.0,10.0,2.2 \mathrm{~Hz}, 1 \mathrm{H}$, allyl), 3.23 (dd, $J=10.0,8.0 \mathrm{~Hz}, 1 \mathrm{H}$, ICH), 3.33 (dd, $J=10.0,4.0 \mathrm{~Hz}, 1 \mathrm{H}, \mathrm{ICH}), 4.65-4.82(\mathrm{~m}, 1 \mathrm{H}, \mathrm{OCH}), 5.20$ (br s, $1 \mathrm{H},=\mathrm{CH}$ ), $7.32-7.46$ $(\mathrm{m}, 6 \mathrm{H}), 7.55-7.66(\mathrm{~m}, 4 \mathrm{H}) ;{ }^{13} \mathrm{C}$ NMR $(75 \mathrm{MHz}) \delta-4.7,10.4,36.9,81.3,114.1,127.9,129.7,134.5$, 134.9, 158.5: mass spectrum, $m / z$ (relative intensity) $406\left(\mathrm{M}^{+}, 50\right), 279$ (30), 197 (100); HRMS calcd for $\mathrm{C}_{18} \mathrm{H}_{19} \mathrm{IOSi} \mathrm{m} / 2406.0250$, found 406.0248 .

6-Methyldiphenylsilyl-5-phenylselenenyl-2-phenylselenenylmethyl-3,4-dihydro-2H-pyran (19). A solution of $83 \mathrm{mg}(0.18 \mathrm{mmol})$ of $12 \mathrm{a}$ and $36 \mathrm{mg}(0.19 \mathrm{mmol})$ of phenylselenenyl chloride in $1.0 \mathrm{~mL}$ of dichloromethane was stirred at room temperature for $3 \mathrm{~h}$ and then partitioned between $20 \mathrm{~mL}$ of ether and 20 $\mathrm{mL}$ of water. The organic layer was washed with $10 \mathrm{~mL}$ of brine, dried $\left(\mathrm{MgSO}_{4}\right)$, and concentrated in vacuo. The residual oil was chromatographed over silica gel (eluted with dichloromethane/hexane $=15 / 85$ ) to give 91 mg (83\%) of 19 as a yellow liquid: IR (neat) $1572 \mathrm{~cm}^{-1}$; ${ }^{1} \mathrm{H} \mathrm{NMR}(200 \mathrm{MHz}) \delta 0.77\left(\mathrm{~s}, 3 \mathrm{H}, \mathrm{SiCH}_{3}\right), 1.70$ $1.92(\mathrm{~m}, 1 \mathrm{H}), 2.00-2.50(\mathrm{~m}, 3 \mathrm{H}), 2.99$ (dd, $J=12.4,6.6 \mathrm{~Hz}, 1 \mathrm{H}, \mathrm{SeCH}$ ), 3.17 (dd, $J=12.4,6.4 \mathrm{~Hz}, 1$ H, SeCH), 3.98-4.14 (m, $1 \mathrm{H}, \mathrm{OCH}), 7.00-7.18(\mathrm{~m}, 5 \mathrm{H}), 7.18-7.42(\mathrm{~m}, 9 \mathrm{H}), 7.42-7.56(\mathrm{~m}, 2 \mathrm{H})$, 7.56$7.75(\mathrm{~m}, 4 \mathrm{H}) ;{ }^{13} \mathrm{C}$ NMR $(50 \mathrm{MHz}) \delta-1.7,28.6,29.1,32.1,74.1,115.1,126.0,126.9,127.5,128.7$, $129.0,130.2,130.4,132.6,135.1,136.1$; mass spectrum, $m / z$ (relative intensity) $606\left(\mathrm{M}^{+}, 64\right), 604$ (57), 602 (31), 197 (100); HRMS calcd for $\mathrm{C}_{31} \mathrm{H}_{31} \mathrm{OSeSi} \mathrm{m} / 2$ 606.0396, found 606.0392 .

5-Bromo-6-methyldiphenylsilyl-2-phenylselenenylmethyl-3,4-dihydro-2H-pyran (20). According to the procedure for the preparation of 19 , the reaction of $55 \mathrm{mg}(0.12 \mathrm{mmol})$ of $12 \mathrm{a}$ and $40 \mathrm{mg}(0.12 \mathrm{mmol})$ of pyridinium perbromide in $1 \mathrm{~mL}$ of NMP gave $38 \mathrm{mg}(59 \%)$ of 20 as an unstable yellow oil: 'H NMR (200 $\mathrm{MHz}) \delta 0.78\left(\mathrm{~s}, 3 \mathrm{H}, \mathrm{SiCH}_{3}\right), 1.70-2.06(\mathrm{~m}, 1 \mathrm{H}), 2.06-2.16(\mathrm{~m}, 1 \mathrm{H}), 2.30-2.65(\mathrm{~m}, 2 \mathrm{H}), 2.92$ (dd, $J=$ 
12.5, 6.6 Hz, $1 \mathrm{H}, \mathrm{SeCH}$ ), 3.07 (dd, $J=12.5,6.4 \mathrm{~Hz}, 1 \mathrm{H}, \mathrm{SeCH}$ ), 3.83-4.00 (m, 1 H, OCH), 7.10-7.23 $(\mathrm{m}, 3 \mathrm{H}), 7.23-7.50(\mathrm{~m}, 8 \mathrm{H}), 7.50-7.65(\mathrm{~m}, 4 \mathrm{H}) ;{ }^{13} \mathrm{C}$ NMR $(50 \mathrm{MHz}) \delta-2.3,28.8,31.7,32.1,74.0$, $113.2,127.0,127.6,129.1,129.3,132.5,135.2,153.1$. This bromide is unstable, and we were not able to obtain satisfactory analysis.

4-Methyl-6-methyldiphenylsilyl-2-phenylselenenylmethyl-3,4-dihydro-2H-pyran (22). According to the procedure for the preparation of $12 \mathrm{a}$, the reaction of $27 \mathrm{mg}(0.088 \mathrm{mmol})$ of 21 and $23 \mathrm{mg}(0.097 \mathrm{mmol})$ of phenylselenenyl bromide in $0.5 \mathrm{~mL}$ of dichloromethane at $-78^{\circ} \mathrm{C}$ for 20 min gave $35 \mathrm{mg}(88 \%)$ of 22 as a yellow oil. This material is a $1: 1$ mixture of two diastereomers: IR (neat) $1613 \mathrm{~cm}^{-1}$; ${ }^{1} \mathrm{H} \mathrm{NMR}(300 \mathrm{MHz}) \delta$ $0.61\left(\mathrm{~s}, 3 \mathrm{H}, \mathrm{SiCH}_{3}\right.$ ), 0.90-1.00 (two overlapped $\mathrm{d}, J=6.9 \mathrm{~Hz}$, at 0.95 and $0.97,3 \mathrm{H}, \mathrm{CH}_{3}$ ), 1.33 (q, $J=$ $11.5 \mathrm{~Hz}, 1 \mathrm{H}$ of isomer A), 1.63 (br d, $J=12 \mathrm{~Hz}, 1 \mathrm{H}$ of isomer B), $1.80-1.95$ ( $\mathrm{m}, 1 \mathrm{H}$ of isomer B), 2.07 (br dd, $J=11.5,6.3 \mathrm{~Hz}, 1 \mathrm{H}$ of isomer A), 2.10-2.29 (m, $1 \mathrm{H}$ of isomer B), 2.30-2.47 (m, $1 \mathrm{H}$ of isomer A), 2.95-3.55 (m, $1 \mathrm{H}, \mathrm{SeCH}), 3.10-3.22(\mathrm{~m}, 1 \mathrm{H}, \mathrm{SeCH}), 3.92-4.08(\mathrm{~m}, 1 \mathrm{H}, \mathrm{OCH}), 4.88$ (br s, $1 \mathrm{H}$, $=\mathrm{CH}$ of isomer $\mathrm{A}), 5.02(\mathrm{br} \mathrm{s}, 1 \mathrm{H}$ of isomer $\mathrm{B}), 7.10-7.21(\mathrm{~m}, 3 \mathrm{H}), 7.24-7.48(\mathrm{~m}, 8 \mathrm{H}), 7.53-7.65(\mathrm{~m}, 4$ H). Anal. Calcd for $\mathrm{C}_{26} \mathrm{H}_{28} \mathrm{OSeSi}$ : C, 67.37; $\mathrm{H}, 6.09$. Found: $\mathrm{C}, 67.02 ; \mathrm{H}, 6.02$.

3-Methyl-6-methyldiphenylsilyl-2-phenylselenenylmethyl-3,4-dihydro-2H-pyran (24). According to the procedure for the preparation of $12 \mathrm{a}$, the reaction of $30 \mathrm{mg}(0.097 \mathrm{mmol})$ of 23 and $21 \mathrm{mg}(0.10 \mathrm{mmol})$ of phenylselenenyl chloride in $1.0 \mathrm{~mL}$ of dichloromethane at $-78^{\circ} \mathrm{C}$ for $20 \mathrm{~min}$ gave $28 \mathrm{mg}(62 \%)$ of 24 as a yellow oil. This material is a 2.2:1 mixture of two diastereomers: IR (neat) $1610 \mathrm{~cm}^{-1} ;{ }^{1} \mathrm{H} \mathrm{NMR}(300 \mathrm{MHz}) \delta$ $0.63\left(\mathrm{~s}, 3 \mathrm{H}, \mathrm{SiMe}_{3}\right), 0.92\left(\mathrm{~d}, J=6.5 \mathrm{~Hz}, 2.2 \mathrm{H}, \mathrm{CH}_{3}\right.$ of the minor isomer), 0.96 (d, $J=6.5 \mathrm{~Hz}, 0.8 \mathrm{H}, \mathrm{CH}_{3}$ of the major isomer), $1.65-1.78(\mathrm{~m}, 1 \mathrm{H}), 1.95-2.18(\mathrm{~m}, 1.7 \mathrm{H}), 2.25-2.36(\mathrm{~m}, 0.3 \mathrm{H}), 2.90$ (dd, $J=12.3$, $5.7 \mathrm{~Hz}, 0.3 \mathrm{H}, \mathrm{SeCH}$ of the minor isomer), $3.10-3.26(\mathrm{~m}, 1.7 \mathrm{H}), 3.76(\mathrm{q}, J=7.1 \mathrm{~Hz}, 0.7 \mathrm{H}, \mathrm{OCH}$ of the major isomer), $4.00-4.08(\mathrm{~m}, 0.3 \mathrm{H}, \mathrm{OCH}$ of minor isomer), 4.98 (br s, $0.3 \mathrm{H},=\mathrm{CH}$ of the minor isomer), 5.03 (br s, $0.7 \mathrm{H},=\mathrm{CH}$ of the major isomer), 7.12-7.25 (m, $3 \mathrm{H}), 7.25-7.42(\mathrm{~m}, 6 \mathrm{H}), 7.42-7.52(\mathrm{~m}, 2 \mathrm{H})$, 7.56-7.68 (m, $4 \mathrm{H})$; mass spectrum, $m / z$ (relative intensity) $464\left(\mathrm{M}^{+}, 53\right), 387$ (21), 307 (52), 197 (100), 137 (20), 83 (76); HRMS calcd for $\mathrm{C}_{21} \mathrm{H}_{26} \mathrm{O}_{2} \mathrm{Si} m / z$ 464.1074, found 464.1076.

\section{5-Methyldiphenylsilyl-3-phenyl-4-phenylselenenyl-2-phenylselenenylmethyl-2,3-dihydrofuran}

(26). According to the procedure for the preparation of 16, the reaction of $200 \mathrm{mg}(0.562 \mathrm{mmol})$ of $25^{19}$ and $360 \mathrm{mg}(1.88 \mathrm{mmol})$ of phenylselenenyl chloride in $2.0 \mathrm{~mL}$ of NMP and stirred at room temperature for $20 \mathrm{~h}$ to give $197 \mathrm{mg}$ (53\%) of $\mathbf{2 6}$ as a yellow oil. This material is a 2:1 mixture of two diastereomers: IR (neat) 1572 $\mathrm{cm}^{-1}$; ${ }^{1} \mathrm{H}$ NMR (300 MHz) major isomer: $\delta 1.03\left(\mathrm{~s}, 3 \mathrm{H}, \mathrm{SiCH}_{3}\right), 3.20$ (dd, $J=12.3,7.7 \mathrm{~Hz}, 1 \mathrm{H}, \mathrm{SeCH}$ ), 3.37 (dd, $J=12.3,5.0 \mathrm{~Hz}, 1 \mathrm{H}, \mathrm{SeCH}), 3.96(\mathrm{~d}, J=4.9 \mathrm{~Hz}, 1 \mathrm{H}, \mathrm{PhCH}), 4.80-4.90(\mathrm{~m}, 1 \mathrm{H}, \mathrm{OCH}), 7.12-$ $7.45(\mathrm{~m}, 13 \mathrm{H}), 7.45-7.60(\mathrm{~m}, 8 \mathrm{H}), 7.74-7.90(\mathrm{~m}, 4 \mathrm{H})$; characteristic signals for the minor isomer: $\delta 1.05$ (s, $3 \mathrm{H}, \mathrm{SiCH}_{3}$ ), 2.79 (dd, $J=12.6,7.8 \mathrm{~Hz}, 1 \mathrm{H}, \mathrm{SeCH}$ ), 3.11 (dd, $\left.J=12.6,7.5 \mathrm{~Hz}, \mathrm{SeCH}\right), 4.10$ (d, $J=$ $7.5 \mathrm{~Hz}, 1 \mathrm{H}, \mathrm{PhCH}), 5.02\left(\mathrm{q}, J=7.5 \mathrm{~Hz}, 1 \mathrm{H}, \mathrm{OCH}\right.$ ); mass spectrum, $\mathrm{m} / z$ (relative intensity) $669\left(\mathrm{M}^{+}, 26\right)$, 354 (34), 197 (100), 157 (25); HRMS calcd for $\mathrm{C}_{36} \mathrm{H}_{32} \mathrm{OSe}{ }_{2} \mathrm{Si} \mathrm{m} / 2668.0633$, found 668.0593.

Acknowledgments. Financial support by the National Science Council of the Republic of China is gratefully acknowledged. 


\section{REFERENCES AND NOTES}

1. For reviews about acylsilanes, see: (a) Ricci, A.; Degi'Innocenti, A. Synthesis 1989, 647-660. (b) Page, P. C. B.; Klair, S. S.; Rosenthal, S. Chem. Soc. Rev. 1990, 19, 147-195. (c) Cirillo, P. F.; Panek, J. S. Org. Prep. Proc. Int. 1992, 24, 553-582.

2. For examples, see: (a) Cirillo, P. F.; Panek, J. S.; J. Org. Chem. 1994, 59, 3055-3063. (b) Nakada, M.; Urano, Y.; Kobayashi, S.; Ohno, M. Tetrahedron Lett. 1994, 35, 741-744.

3. (a) Brook, A. G.; Pierce, J. B.; Duff, J. M. Can. J. Chem. 1975, 53, 2874-2879. (b) Ando, W.; Sekiguchi, A. J. Organomet. Chem. 1977, 133, 219-230.

4. For some recent examples, see: (a) Morihata, K.; Horiuchi, Y.; Taniguchi, M.; Ohima, K.; Utimoto, K. Tetrahedron Lett. 1995, 36, 5555-5558. (b) Takeda, K.;Nakajima, A.; Takeda, M.; Okamoto, Y.; Sato, T.; Yoshii, E.; Koizumi, T.; Shiro, M. J. Am. Chem. Soc. 1998, 120, 4947-4959. (c) Horiuchi, Y.; Oshima, K.; Utimoto, K. J. Org. Chem. 1996, 61, 4483-4486. (d) Takeda, K; Tanaka, T. Synlett $1999,705-708$.

5. (a) Chang, S.-Y.; Jiaang, W.-T.; Cherng, C.-D.; Tang, K.-H.; Huang, C.-H.; Tsai, Y.-M. J. Org. Chem. 1997, 62, 9089-9098. (b) Jiaang, W.-T.; Lin, H.-C.; Tang, K.-H.; Chang, L.-B.; Tsai, Y.-M. J. Org. Chem. 1999, 64, 618-628.

6. Tsai, Y.-M.; Nieh, H.-C.; Cherng, C.-D. J. Org. Chem. 1992, 57, 7010-7012.

7. For reviews about the preparation of furan and pyran derivatives in general, see: (a) Boivin, T. L. B. Tetrahedron 1987, 43, 3309-3362. (b) Wong, H. N. C. Pure Appl. Chem. 1996, 68, 335-344. (c) Harmange, J.-C.; Figadère, B. Tetrahedron Asym. 1993, 4, 1711-1754.

8. For the sulfur analog of this reaction, see: (a) Bonini, B. F.; Comes-Franchini, M.; Mazzanti, G.; Ricci, A.; Rosa-Fauzza, L.; Zani, P. Tetrahedron Lett. 1994, 35, 9227-9228. (b) Bonini, B. F.; ComesFranchini, M.; Fochi, M.; Mazzanti, G.; Ricci, A. Tetrahedron 1996, 52, 4803-4816.

9. (a) Crandall, J. K.; Magaha, H. S. J. Org. Chem. 1982, 47, 5368-5371. (b) Shenvi, A. B.; Ciganek, E. J. Org. Chem. 1984, 49, 2942-2947.

10. Yates, K.; Agolini, F. Can. J. Chem. 1966, 44, 2229-2231.

11. (a) Siedem, C. S.; Molander, G. A. J. Org. Chem. 1996,61, 1140-1142. (b) Molander, G. A.; Siedem, C. S. J. Org. Chem. 1995, 60, 130-138.

12. Saleur, D.; Bouillon, J.-P.; Portella, C. Tetrahedron Lett. 1999, 40, 1885-1886.

13. Lukevics, E.; Gevorgyan, V. N.; Goldberg, Y. S.; Shymanska, M. V. J. Organomet. Chem. 1985, 294, $163-171$.

14. Rautenstrauch, V. Helv. Chim. Acta 1972, 55, 594-609.

15. Bartlett, P. A. in Asymmetric Synthesis; Morrison, J. D., Ed.; Academic Press: New York, 1984; Vol. $3 B, p 411$.

16. (a) Brook, A. G.; Duff, J. M.; Jones, P. F.; Davis, N. R. J. Am. Chem. Soc. 1967, 89, 431-434. (b) Corey, E. J.; Seebach, D.; Freedman, R. J. Am. Chem. Soc. 1967, 89, 434-436.

17. Chuang, T.-H.; Fang, J.-M.; Jiaang, W.-T.; Tsai, Y.-M. J. Org. Chem. 1996, 61, 1794-1805.

18. For similar transformation, see: Engman, L.; Gupta, V. J. Org. Chem. 1997, 62, 157-173.

19. (a) Helferich, B.; Gehrke, M. Chem. Ber. 1921, 54, 2640-2647. (b) Paul, R.; Tcheltcheff, S. Bull. Soc. Chim. Fr. 1952, 808-814.

20. (a) Clive, D. L. J.; Russell, C. G. Tetrahedron 1980, 36, 1399-1408. (b) Nicolaou, K. C. Tetrahedron 1981, 37, 4097-4109. (c) Bartlett, P. A.; Richardson, D. P.; Myerson, J. Tetrahedron 1984, 40, $2317-$ 2327.

21. (a) Maruoka, K.; Banno, H.; Yamamoto, H. J. Am. Chem. Soc. 1990, 112, 7791-7793. (b) Maruoka, K.; Banno, H.: Yamamoto, H. Tetrahedron Asym. 1991, 2, 647-662.

22. Bennett, F.; Knight, D. W.; Fenton, G. J. Chem. Soc. Perkin Trans. 1, 1991, 133-140.

23. In more substituted systems, better stereo-selectivity can be obtained, see: Greeves, N.; Lee, W.-M.; Barkley, J. V. Tetrahedron Lett. 1997, 38, 6453-6456.

24. Becker, D.; Haddad, N. Tetrahedron 1993, 49, 947-964.

25. Bromidge, S. M.; Sammes, P. G.; Street, L. J. J. Chem. Soc. Perkin Trans. 1, 1985, 1725-1730. 